Artur Żyto

Uniwersytet im. Adama Mickiewicza w Poznaniu

artur.zyto@amu.edu.pl

\title{
Znaczenie dziedzictwa kulturowego dla rozwoju turystyki w rejonie Parku Narodowego Gór Stołowych
}

\section{Streszczenie}

Wzrastający ruch turystyczny w Górach Stołowych generuje potrzebę jego deglomeracji, co możliwe jest m.in. poprzez wykorzystanie obiektów dziedzictwa kulturowego. Celem rozdziału jest określenie ich znaczenia dla rozwoju turystyki na badanym obszarze. W tekście przedstawiono preferencje turystów dotyczące wyboru odwiedzanych atrakcji kulturowych, ich przegląd, a także ogólną charakterystykę zasobów kulturowych na terenie Parku Narodowego Gór Stołowych. Metodyka badań obejmowała pozyskanie danych od turystów przy użyciu kwestionariusza wywiadu oraz inwentaryzację terenową. Dziedzictwo kulturowe Gór Stołowych jest komplementarnym celem wyjazdów turystycznych. Turystyka kulturowa rozwija się głównie w większych miejscowościach, a obiekty kulturowe na obszarze parku wymagają promocji i udostępnienia, np. w postaci szlaków tematycznych.

\section{Wprowadzenie}

Obszary o nagromadzeniu wysokich walorów przyrodniczych sprawiają, że ruch turystyczny w ich otoczeniu systematycznie wzrasta (Łysoń, 2019). Przykładem tego typu regionu w południowej części Polski są Sudety, gdzie rozwój turystyki stymulowany jest przede wszystkim na terenie dwóch parków narodowych - Karkonoskiego oraz Gór Stołowych (dalej: PNGS). Funkcja turystyczna obszarów prawnie chronionych może być postrzegana jako konfliktogenna (Stasiak, 1997), ze względu na konieczność równoczesnego pełnienia zadań ochronnych, edukacyjnych, jak i udostępniania cennego obszaru (ustawa z dnia 16 kwietnia 2004 r. o ochronie przyrody). Jednym z możliwych do zastosowania środków,

Cytowanie: Żyto A. (2021). Znaczenie dziedzictwa kulturowego dla rozwoju turystyki w rejonie Parku Narodowego Gór Stołowych. W: K. Borodako (red.), Turystyka w okresie pandemii. Bogucki Wydawnictwo Naukowe, Poznań-Kraków, s. 165-174. https://doi.org/10.12657/9788379863501-16 
łagodzącym konflikty związane $z$ ochroną przyrody i ich turystyczną penetracją, jest odpowiednie kierowanie ruchem turystycznym oraz limitowanie jego wielkości (Stasiak, 1997). Z tego powodu w destynacjach narażonych na zwiększony ruch turystyczny należy opracować rozwiązania służące kontrolowanej dyspersji turystycznej. Proces ten przebiegać może w oparciu o wypromowane i udostępnione obiekty dziedzictwa kulturowego, rozumianego jako całość materialnego i niematerialnego dorobku społeczeństwa (Kozioł i in., 2013), które często pełnią rolę komplementarnych walorów turystycznych regionu.

Głównym celem rozdziału jest określenie roli dziedzictwa kulturowego w rozwoju turystyki w rejonie Gór Stołowych. W ramach jego realizacji określono cele cząstkowe, do których zaliczono przedstawienie przeglądu najważniejszych atrakcji kulturowych obszaru oraz rozpoznanie obiektów będących zasobami kulturowymi, zlokalizowanych w granicach PNGS.

Metodyka obejmowała badania sondażowe techniką PAPI w rejonie Błędnych Skał i Szczelińca Wielkiego w latach 2015-2019, na podstawie których uzyskano dane dotyczące najchętniej odwiedzanych atrakcji kulturowych. We wrześniu 2019 r. przeprowadzono ich inwentaryzację, w trakcie której dokonano przeglądu oferty i towarzyszącej im infrastruktury turystycznej. Kontynuacją badań terenowych była inwentaryzacja zasobów kulturowych na obszarze PNGS, która miała miejsce w lipcu $2020 \mathrm{r}$.

\section{Przegląd literatury}

Problematyka dotycząca dziedzictwa kulturowego w rejonie Gór Stołowych została opisana przez Latochę (2011, 2012, 2017), Latochę i Roszczewską (2011) oraz Latochę i Migonia (2018), a w szczególności w pierwszym monograficznym opracowaniu poświęconym temu tematowi (Latocha 2020). W innym ujęciu Rogowski i Żyto (2018) przedstawili profile turystów kulturowych, koncentrując się na podobieństwach i różnicach w zakresie motywów, preferencji i zachowań w stosunku do ogółu przyjezdnych i określili ich ogólny udział w strukturze ruchu turystycznego. Szereg zapisów odnoszących się do uwarunkowania i rozwoju turystyki kulturowej znalazł się w „Strategii rozwoju turystyki w Parku Narodowym Gór Stołowych" (Czerniak, 2020).

Czynnikiem motywującym do podróży kulturowych w rejonie Gór Stołowych jest bogate dziedzictwo kulturowe tego transgranicznego obszaru. Obejmuje ono wielonarodową i wielokulturową spuściznę wyrażaną poprzez obiekty materialne, wytworzone przez przedstawicieli różnych narodowości (polskiej, niemieckiej i czeskiej) i wyznań oraz przekazywane z pokolenia na pokolenie wartości, tradycje i praktyki. Jego współczesnym wyrazem jest przede wszystkim willowa zabudowa miejscowości uzdrowiskowych wraz z parkami zdrojowymi, obiekty militarne, sakralne (kościoły, kapliczki, krzyże przydrożne, krzyże pokutne), ruiny zamków, skanseny, muzea, zabudowa wiejska śląsko-czeskiego pogranicza, a także cykliczne wydarzenia kulturalne, m.in. Międzynarodowy Festiwal Chopinowski, Festiwal Moniuszkowski i Święto Papieru. Zgodnie z periodyzacją 
dziejów turystyki sudeckiej (Potocki, 2012), większość zachowanych do dzisiaj obiektów materialnych ma swoje początki w okresie niemieckim, datowanym od zakończenia wojny siedmioletniej w 1763 r. (Staffa i in., 1992).

Jeżeli zwiedzanie obiektów dziedzictwa kulturowego nie jest dla turystów głównym motywem podejmowanych podróży, a przyrodnicze cele wyjazdu związane są ze środowiskiem gospodarowanym przez człowieka (np. parki narodowe), to osoby te można postrzegać jako tzw. turystów przyrodniczo-kulturowych (Mikos von Rohrscheidt, 2016). Zgodnie z szerszym ujęciem definicji turysty kulturowego, grupę tę będą tworzyć osoby korzystające podczas wyjazdu z oferty kulturowej lub zawierającej elementy kulturowe (obok innych propozycji turystycznych), dla których występowanie tego typu walorów/atrakcji nie jest decydującym motywem podjęcia podróży (Mikos von Rohrscheidt, 2008a). Atrakcje kulturowe stają się komplementarne względem głównej, rozpoznawalnej na rynku „marki turystycznej” regionu, którą w przypadku badanego obszaru jest PNGS (Kruczek, 2017). W literaturze anglojęzycznej pojęcie turystyki przyrodniczo-kulturowej można porównywać do ekoturystyki, w ramach której kreuje się ofertę turystyczną opartą na walorach przyrodniczych i kulturowych, co staje się narzędziem zrównoważonego rozwoju obszarów cennych przyrodniczo (Aciksoz $\mathrm{i}$ in., 2010; Cajee, 2014; Carvache-Franco i in., 2019; Sgroi, 2020; Wei i in., 2020).

\section{Wyniki badań}

\section{Struktura ruchu turystycznego}

Charakterystykę struktury ruchu turystycznego na obszarze PNGS przeprowadzono w oparciu o wyniki uzyskane z 3305 prawidłowo wypełnionych kwestionariuszy ankiet. Badania sondażowe zrealizowane zostały przez grupę studentów działających w Studenckim Kole Naukowym Geografów im. S. Pawłowskiego w latach 2015-2019. W niniejszym opracowaniu przytoczono jedynie część wyników powiązaną z podjętą problematyką badawczą.

Turyści, dla których głównym celem przyjazdu na badany obszar był motyw kulturowy, rozumiany jako "poznanie i podziwianie obiektów zabytkowych", stanowią co roku najmniejszy odsetek spośród innych możliwych do wyboru motywów (1-2\%). Analiza drugorzędnych celów podejmowania podróży pozwala zidentyfikować $\mathrm{w}$ strukturze ruchu turystycznego turystów o profilu przyrodniczo-kulturowym. Dla tej grupy osób (14-27\%) kontakt z dziedzictwem kulturowym lub uczestnictwo w wydarzeniach kulturalnych jest istotnym komplementarnym czynnikiem motywujący do wypoczynku w Górach Stołowych.

Badani, oprócz Szczelińca Wielkiego i Błędnych Skał, odwiedzali najczęściej: Kudowę-Zdrój (11-14\%), Duszniki-Zdrój (3-6\%), Wambierzyce (5-11\%) oraz Kaplicę Czaszek w Czermnej (3-12\%). Wszystkie miejscowości zlokalizowane

Kafeteria odpowiedzi zawarta w kwestionariuszu wywiadu zawierała również opcję „Uczestnictwo w ofercie wydarzeń kulturalnych", co nie zostało jednak nigdy wskazane przez ankietowanych. 
są wokół PNGS, który jest zarówno centralnie położoną atrakcją turystyczną, jak i obszarem tranzytowym. Na tej podstawie wyróżnić można potencjalne miejscowości uprawiania turystyki kulturowej, które mogłyby być chętniej odwiedzane przez turystów pod warunkiem odpowiedniego wypromowania znajdujących się tam walorów antropogenicznych. Część z nich znajduje się poza regionem Gór Stołowych, jednak pozostają one w przestrzeni penetracji turystycznych turystów wypoczywających na badanym obszarze (ryc. 1).

\section{Lokalizacja atrakcji kulturowych w rejonie Gór Stołowych}

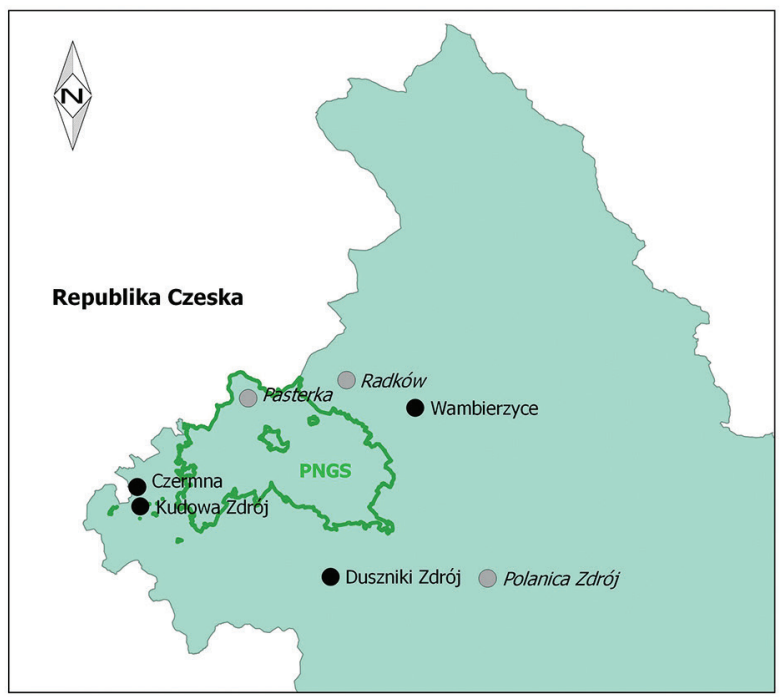

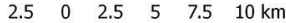

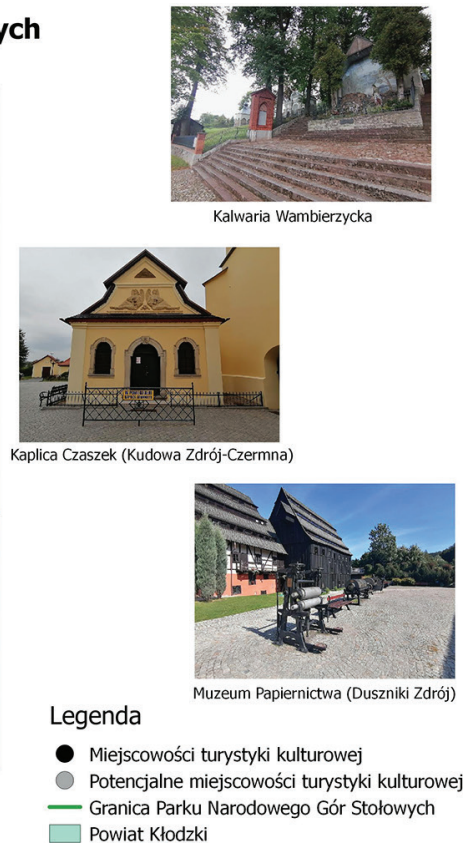

Ryc. 1. Lokalizacja głównych atrakcji kulturowych w rejonie Gór Stołowych Źródło: opracowanie własne.

\section{Kulturowe atrakcje turystyczne}

Najchętniej odwiedzaną destynacją kulturową w Górach Stołowych jest Kudowa-Zdrój, w której granicach mieszczą się również obecnie dawne wioski: Czermna i Pstrążna. Szczególny rozwój miasta przypadł na okres zaboru pruskiego, kiedy to wzniesiono wiele zabudowań związanych $z$ rozwojem i funkcjonowaniem uzdrowiska, w tym charakterystyczną zabudowę willową i park zdrojowy.

Drugim pod względem popularności miastem turystyczno-uzdrowiskowym są Duszniki-Zdrój, których rozwój wynika również ze znajdującego się w jego granicach kurortu narciarskiego - Zieleniec Ski Arena.

Ważnym ośrodkiem kulturowo-religijnym są Wambierzyce, nazywane Dolnośląską Jerozolimą. Określenie to zawdzięczają kalwarii rozbudowywanej od XVIII do XX w. Ten rozległy zespół krajobrazowo-architektoniczny jest jednym z największych tego typu w Polsce i w Europie. Najważniejsze obiekty dziedzictwa 
kulturowego regionu Gór Stołowych, w powiązaniu z możliwymi rozwiniętymi w oparciu o nie rodzajami turystyki kulturowej, zestawiono w tabeli 1.

Tabela 1. Kulturowe atrakcje turystyczne rejonu Gór Stołowych

\begin{tabular}{|c|c|c|}
\hline & Przykładowe atrakcje turystyczne & $\begin{array}{c}\text { Rodzaje } \\
\text { turystyki } \\
\text { kulturowej }\end{array}$ \\
\hline Kudowa-Zdrój & $\begin{array}{l}\text { Park Zdrojowy, neobarokowa pijalnia wód leczniczych, } \\
\text { Sanatorium Polonia z Teatrem Zdrojowym (1905 r.), } \\
\text { Hala Spacerowa „Teatr pod Blachą”, ewangelicko-au- } \\
\text { gsburska kaplica pw. Chrystusa Króla (1798 r.), Altana } \\
\text { Miłości (punkt widokowy na miasto), Muzeum Kultu- } \\
\text { ry Ludowej Przedgórza Sudeckiego, Skansen w Pstrąż- } \\
\text { nej, Muzeum Minerałów, Muzeum Zabawek, Kaplica } \\
\text { Czaszek i kościół pw. św. Bartłomieja z cmentarzem } \\
\text { parafialnym (XVIII w.), ruchoma szopka w Czermnej } \\
\text { (XIX w.), Gospodarstwo „Szlak Ginących Zawodów” }\end{array}$ & \multirow{3}{*}{$\begin{array}{l} \\
\text { dziedzictwa } \\
\text { kulturowego, } \\
\text { prawnie } \\
\text { chronionego } \\
\text { dziedzictwa } \\
\text { kulturowego, } \\
\text { muzealna, } \\
\text { religijna, } \\
\text { hobbystyczna, } \\
\text { obiektów za- } \\
\text { bytkowych, } \\
\text { stylów archi- } \\
\text { tektonicznych, } \\
\text { etniczna (sen- } \\
\text { tymentalna), } \\
\text { kultury ludo- } \\
\text { wej, eventowa }\end{array}$} \\
\hline Duszniki-Zdrój & $\begin{array}{l}\text { Muzeum Papiernictwa - obiekt wpisany na listę Po- } \\
\text { mników Historii, XIX-wieczna pijalnia wód mineral- } \\
\text { nych z Pawilonem Muzycznym, Szpital Uzdrowiskowy } \\
\text { Jan Kazimierz, Teatr Zdrojowy, Pawilon Źródła Pie- } \\
\text { niawa Chopina, Kolorowa Fontanna, kościół pw. NSPJ } \\
\text { (1899-1902), kamienice wraz z ratuszem (XVI, XVIII, } \\
\text { XIX w.), pomnik Sybiraków, pręgierz, kolumna wotyw- } \\
\text { na Matki Boskiej z Dzieciątkiem (1725 r. jako wotum } \\
\text { za uratowanie miasta od zarazy), kościół pw. Matki } \\
\text { Bożej Różańcowej z lapidarium (1845-1846, świątynia } \\
\text { ewangelicka, obecnie polskokatolicka), kościół św. św. } \\
\text { Apostołów Piotra i Pawła (1708-1730), barokowa bu- } \\
\text { dowla, w której wnętrzu uwagę zwraca ambona - tzw. } \\
\text { „dusznicki wieloryb” - nawiązująca do motywu biblij- } \\
\text { nego Jonasza, będącego symbolem zmartwychwstania } \\
\text { w czeskim, bawarskim i austriackim baroku }\end{array}$ & \\
\hline Wambierzyce & $\begin{array}{l}\text { Sanktuarium Wambierzyckiej Królowej Rodzin (XVIII w.), } \\
\text { Kalwaria Wambierzycka, ruchoma szopka (XIX w.) }\end{array}$ & \\
\hline
\end{tabular}

Źródło: opracowanie własne na podstawie Ryś (2000), Papaj (2015), Staffa i in. (1992), http://parafiaduszniki.pl/, http://visitduszniki.pl/.

\section{Kulturowe zasoby turystyczne Parku Narodowego Gór Stołowych}

Na podstawie inwentaryzacji terenowej zidentyfikowano na obszarze PNGS 94 punktowe obiekty kulturowe. W grupie tej znalazły się m.in. pozostałości fortu Karola oraz schronisko PTTK „Na Szczelińcu”, które stanowią przykład miejsc chętnie odwiedzanych przez turystów. Z tego względu wyróżniają się W grupie zasobów kulturowych i należy je postrzegać jako atrakcje turystyczne. Rozmieszczenie potencjalnych walorów kulturowych jest nierównomierne, a w dodatku nie wszystkie obiekty znajdują się obecnie bezpośrednio przy szlakach turystycznych (ryc. 2). 


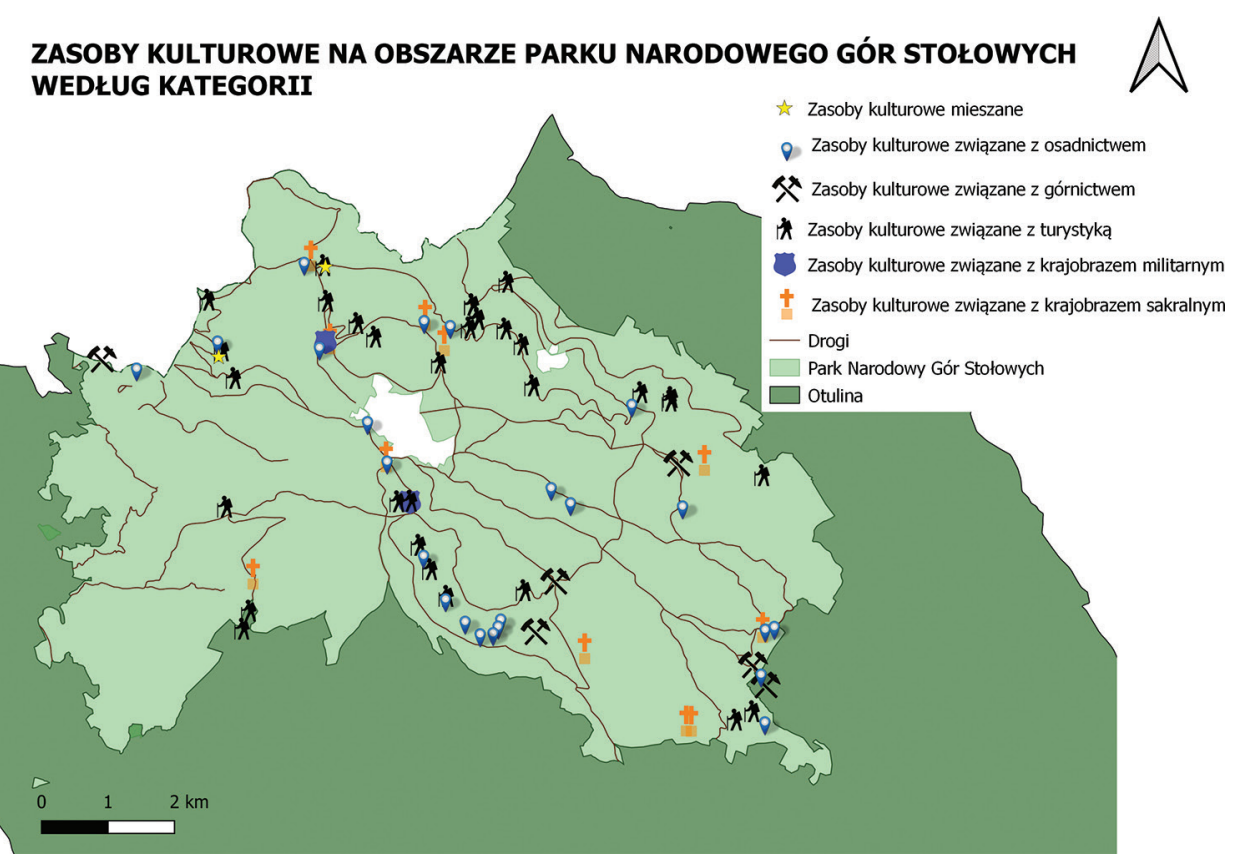

Ryc. 2. Zasoby turystyczne na obszarze Parku Narodowego Gór Stołowych Źródło: opracowanie własne.

Badania terenowe umożliwiły dokonanie wstępnej klasyfikacji tematycznej zasobów kulturowych, w której odniesiono się przede wszystkim do pierwotnych funkcji poszczególnych obiektów. Najbardziej liczną kategorię stanowi grupa obiektów związanych z osadnictwem (35). Umieszczono w niej artefakty będące wynikiem przekształcania przez człowieka terenu, których nie sklasyfikowano $\mathrm{w}$ ramach pozostałych, węższych pojęciowo grup tematycznych. W drugiej pod względem liczebności grupie znalazły się obiekty, które pojawiły się w krajobrazie Gór Stołowych w związku z rozwojem turystyki na tym obszarze, m.in. kamienne szlakowskazy, punkty widokowe, zabytkowa infrastruktura turystyczna (31). Do grupy obiektów skategoryzowanych pod nazwą „krajobraz sakralny" zaliczono kapliczki, krzyże oraz pozostałe elementy wpisujące się w definicję krajobrazu sakralnego, zaproponowaną przez Lehmanna (2007; za: Holly, 2014), dla którego obejmuje on „dziedzictwo duchowe i kulturowe wyrażone za pomocą obiektów sakralnych w krajobrazie" (16). Wśród zasobów kulturowych odnoszących się do górnictwa uwzględniono przede wszystkim pozostałości infrastruktury związanej z dawnym funkcjonowaniem kamieniołomów (8). Najmniej liczne grupy (po 2 obiekty) dotyczą krajobrazu militarnego (pozostałości bastionów) oraz tzw. zasobów kulturowych mieszanych, które składają się z obiektów o różnej funkcji, zlokalizowanych bezpośrednio w sąsiedztwie - przy schronisku „Na Szczelińcu” oraz w Ostrej Górze. Przykłady zinwentaryzowanych zasobów turystycznych zamieszczono w tabeli 2. 
Tabela 2. Wybrane obiekty kulturowe na obszarze PNGS według kategorii

$$
\text { Przykładowe obiekty dziedzictwa kulturowego }
$$

Osadnictwo Kamienie graniczne włości, drogowskazy, odrestaurowany system kaskadowych suchych zbiorników retencyjnych, elementy infrastruktury drogowej, pomnik pamięci, pozostałości zabudowań w dawnych wsiach (np. Karłówek), pozostałości huty szkła w Batorowie, drewniana dzwonnica sygnałowa.

Turystyka Szlakowskazy, wyrzeźbione w skałach „kanapy i fotele” wypoczynkowe na szlaku, tablice edukacyjne, punkty widokowe, infrastruktura turystyczna przy wodospadzie Pośny, pomnik „Serce pozostawione w Pasterce”.

Krajobraz Kapliczki, krzyże, XVIII-wieczny kościół pw. św. Jana Chrzciciela w Pastersakralny ce wraz z cmentarzem, XVIII-wieczna kaplica pw. św. Anny na Wzgórzu św. Anny w Batorowie wraz z kalwarią, fragment ścieżki pątniczej do Wambierzyc.

Górnictwo Odsłonięcia skalne, pochylnie, kamienie młyńskie, drogi, schody, kamień górniczy pola górniczego w masywie Skalniaka.

Krajobraz Pozostałości XVIII-wiecznego fortu Karola na górze Ptak, obszar militarny XVIII-wiecznego fortu w Pasterce.

Źródło: opracowanie własne na podstawie inwentaryzacji terenowej (lipiec 2020).

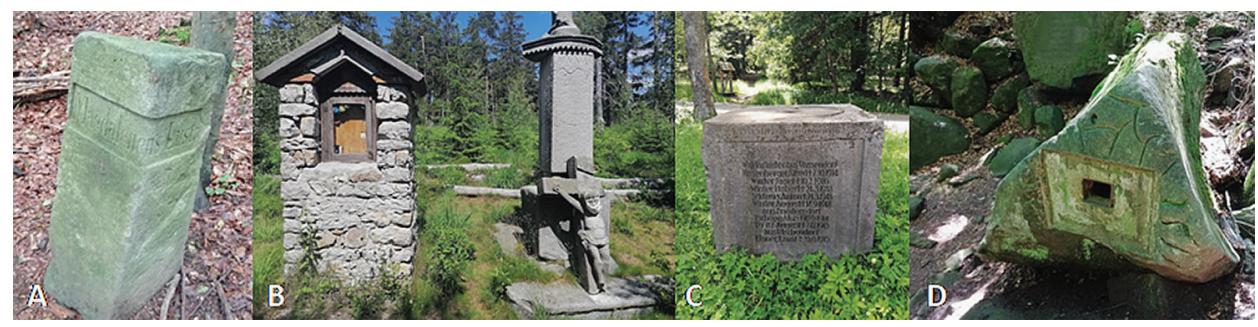

Ryc. 3. Zasoby kulturowe: A. szlakowskaz, B. kapliczka i krzyż na dawnym szlaku pątni-

czym, C. pomnik w Karłowie poświęcony pamięci ofiar I wojny światowej, D. dawna skarbonka dla turystów przy wodospadzie Pośny

Źródło: fot. wykonana przez autora (lipiec 2020).

Zinwentaryzowane obiekty charakteryzują się różnym stopniem zachowania i dostępności. Wiele z nich mogłoby już obecnie wzbogacać ofertę turystyczną PNGS, jednak ze względu na brak odpowiedniej infrastruktury turystycznej wciąż pozostają one zasobami turystycznymi.

\section{Zakończenie}

Zróżnicowane walory i zasoby kulturowe rejonu Gór Stołowych są istotnym czynnikiem, wokół którego można budować szlaki kulturowe oraz produkty turystyczne. Konieczność ich tworzenia znajduje uzasadnienie w narastającym ruchu turystycznym, a także w coraz częściej odczuwanej potrzebie zachowania bezpiecznego dystansu społecznego z powodu epidemii wywołanej wirusem 
SARS-CoV-2. Wzbogacona oferta turystyczna umożliwiłaby dyspersję kierunków zwiedzania, co uchroniłoby cenny przyrodniczo obszar przed przesyceniem turystycznym, a także zwiększyło atrakcyjność turystyczną rejonu. Z drugiej strony istnieje zagrożenie niepożądanego zachowania turystów na szlakach odwiedzanych jak dotąd rzadziej. Dlatego należy wypracować odpowiedni sposób monitoringu ruchu turystycznego oraz uwzględnić działania o charakterze edukacyjnym, zwiększające świadomość ekologiczną odwiedzających. Zarządzający ruchem turystycznym powinni jednakowo troszczyć się o opracowanie i promocję tras przyrodniczych, kulturowych oraz łączących elementy naturalne i antropogeniczne, co może zawierać się $\mathrm{w}$ trasach krajoznawczych. Ich zróżnicowanie może zainteresować różne grupy konsumentów, którzy odpowiednio wypromowany region uznają za atrakcyjny turystycznie. Postrzeganie środowiska geograficznego jako spójnego i funkcjonalnego systemu umożliwia zachowanie jego walorów. Autentyczność ta jest istotna zarówno z punktu widzenia gestorów turystyki, jak i samych turystów. Kreowanie oferty przyrodniczo-kulturowej powinno odbywać się ze szczególnym uwzględnieniem wychowawczej funkcji turystyki, na którą składają się funkcja kształcenia świadomości ekologicznej i funkcja edukacji kulturowej. Za właściwą formę harmonijnego rozwoju turystyki na tym obszarze można uznać ekoturystykę, którą Kurek (2004) wskazuje jako najbardziej optymalną w parkach narodowych. W przestrzeni wytworzonej pomiędzy walorami (atrakcjami) przyrodniczymi a kulturowymi należy stymulować rozwój innych form turystyki, np. geoturystykę, turystykę edukacyjną, turystykę aktywną, które mogą stanowić dodatkowe źródło dochodu dla miejscowej ludności. Równolegle do rozwoju turystyki kulturowej na obszarze parku istnieje potrzeba lepszej promocji obiektów dziedzictwa kulturowego znajdującego się w miejscowościach położonych wzdłuż tras dojazdowych do rozpoznanych już atrakcji kulturowych. Wzbogaciłyby one ofertę $\mathrm{w}$ większości dobrze przygotowanych do obsługi turystów wypromowanych już kulturowych atrakcji turystycznych. Kompleksowemu rozpoznaniu kulturowej atrakcyjności turystycznej tego obszaru może służyć kontynuacja badań, obejmująca m.in. wielowymiarową analizę porównawczą gmin znajdujących się w otulinie PNGS, a także badania związane z oczekiwaniami turystów i oceną atrakcji turystycznych, na których wartość aplikacyjną zwraca uwagę Kruczek (2005). Cały czas aktualne pozostają sugestie wskazane przez Mikosa von Rohrscheidta (2008b), który postulował rozwój na Ziemi Kłodzkiej turystyki militarnej, religijnej, obiektów i zabytków techniki, kulturowo-przyrodniczej, muzealnej i wypraw tematycznych związanych ze sztuką i architekturą. Nie należy pomijać również ważnej w tym regionie turystyki etnicznej Niemców i Czechów (zwłaszcza na obszarze tzw. Czeskiego Kątka²), związanej zarówno z miejscami i obiektami przodków, jak i różnymi wydarzeniami historycznymi i przejawami wytworów kultury.

Wzrost świadomości odwiedzających na temat bogactwa i zróżnicowania dziedzictwa kulturowego rejonu Gór Stołowych może przyczynić się do wzrostu

2 Obszar rozciągający się na południowy zachód od Błędnych Skał - pomiędzy Lewinem a czeskim Náchodem. 
liczby turystów motywowanych walorami antropogenicznymi. Umożliwiłoby to rozwój turystyki kulturowej już nie tylko w oparciu o cykliczne wydarzenia kulturalne, lecz także unikalne obiekty dziedzictwa, które są formą kapitału kulturowego łączącego ludzi ze sobą i środowiskiem (Harrison, 2010, za: Nowacki, 2012). Podstawowym działaniem powinno być opracowanie koncepcji systemu informacji turystycznej objaśniającego znaczenie poszczególnych elementów dziedzictwa kulturowego, a następnie wytyczenie szlaków tematycznych. Proponowane w tym rozdziale działania są zgodne z obowiązującą Strategią Rozwoju Turystyki w PNGS (Czerniak i in., 2020), co nadaje podjętej problematyce badawczej charakter aplikacyjny.

\section{Literatura}

Aciksoz S., Gormus S., Karadeniz N. (2010). Determination of ecotourism potential in national parks: Kure mountains national park, Kastamonu-Bartin, Turkey. African Journal of Agricultural Research, 5(8): 589-599.

Cajee L. (2014). Eco-Cultural Tourism: A Tool for Environmental, Cultural and Economic Sustainability (A Case Study of Darap Village, West Sikkim). SHS Web of Conferences, 12.

Carvache-Franco M., Segarra-Ona M., Carrascosa-Lopez C. (2019). Segmentation and motivations in eco-tourism: The case of a coastal national park. Ocean \& Coastal Management, 178.

Czerniak A. (red.) 2020. Strategia rozwoju turystyki w Parku Narodowym Gór Stołowych. Biuro Urządzania Lasu i Geodezji Leśnej Oddział w Brzegu.

Holly G. (2014). Przekształcenia krajobrazu sakralnego na pograniczu polsko-słowacko-ukraińskim (XIX-XXI wiek). Monografie Bieszczadzkie, 15. Bieszczadzki Park Narodowy, Ustrzyki Dolne.

http://parafiaduszniki.pl/ (dostęp: 20.12.2020).

http://visitduszniki.pl/ (dostęp: 20.12.2020).

Kozioł A., Trelka M., Florjanowicz P. (2013). Społeczno-gospodarcze oddziaływanie dziedzictwa kulturowego. Raport z badań społecznych. Narodowy Instytut Dziedzictwa, Warszawa.

Kruczek Z. (2005). Metody badań atrakcji turystycznych. W: R. Winiarski, W. Alejziak (red.), Turystyka w badaniach naukowych. AWF, Kraków, WZiZ, Rzeszów, s. 35-46.

Kruczek Z. (2017). Frekwencja w polskich atrakcjach turystycznych 2011-2015. Wydawnictwo Proksenia, Kraków.

Kurek W. (2004). Turystyka na obszarach górskich Europy. Instytut Geografii i Gospodarki Przestrzennej Uniwersytetu Jagiellońskiego, Kraków.

Latocha A. (2011). Contemporary landscape of depopulated areas as a mosaic of relict and active landscape features (Stołowe Mts. case study). The Problems of Landscape Ecology, 30: 309-316.

Latocha A. (2012). Śladami dawnego osadnictwa w Sudetach (1) - Karłówek. Sudety, 4(133): $28-31$.

Latocha A. (2017). Odradzanie wsi? Przemiany ludnościowo-osadnicze na ziemi kłodzkiej w okresie powojennym. Studia Obszarów Wiejskich, 48: 29-50.

Latocha A. (2020). Krajobraz kulturowy Gór Stołowych. Wędrówki w czasie i w terenie. Wydawnictwo cyfrowe, Park Narodowy Gór Stołowych. 
Latocha A., Migoń P. (2018). Geneza i przemiany krajobrazu kulturowego Gór Stołowych. W: C. Kabała (red.), Góry Stołowe. Przyroda i ludzie. Park Narodowy Gór Stołowych, Kudowa-Zdrój, s. 47-61.

Latocha A., Roszczewska M. (2011). Zmiany krajobrazu na terenie Parku Narodowego Gór Stołowych w ostatnich stu latach. Przyroda Sudetów, 14: 125-140.

Łysoń P. (2019). Turystyka w Polsce w 2018 roku. GUS, Warszawa.

Mikos von Rohrscheidt A. (2008a). Turystyka kulturowa: fenomen, potencjał, perspektywy. GWSHM Milenium, Gniezno.

Mikos von Rohrshcheidt A. (2008b). Waloryzacja turystyczno-kulturowa miasta i powiatu Kłodzko. Turystyka Kulturowa, 2: 36-47.

Nowacki M. (2012). Dziedzictwo i turystyka: relacje i ewolucja koncepcji. W: B. Włodarczyk, B. Krakowiak (red.), Kultura i turystyka - wspólne korzenie. Regionalna Organizacja Turystyczna Województwa Łódzkiego, Łódź, s. 35-49.

Papaj M. (2015). Kudowa-Zdrój w Górach Stołowych. Wydawnictwo Turystyczne Plan, Jelenia Góra.

Potocki J. (2016). Góry Stołowe i Adsrpassko-Teplicke Skaly. Wydawnictwo Turystyczne Plan, Jelenia Góra.

Rogowski M., Żyto A. (2018). Co turysta kulturowy robi w parku narodowym? Motywy i preferencje turystów kultu-rowych w Parku Narodowym Gór Stołowych. Turystyka Kulturowa, 4: 63-77.

Ryś S. (2000). Kudowa-Zdrój. Przewodnik turystyczny. Wydawnictwo Kartograficzne Karta, Katowice.

Sgroi F. (2020). Forest resources and sustainable tourism, a combination for the resilience of the landscape and development of mountain areas. Science of The Total Environment, 736.

Staffa M., Janczak J., Mazurski K., Zając C., Czerwiński J. (1992). Słownik geografii turystycznej Sudetów. T. 13. Góry Stołowe. Wydawnictwo PTTK „Kraj”, Warszawa-Kraków.

Stasiak A. (1997). Turystyka w parkach narodowych - obszary konfliktów. Turyzm, 7(2): 5-23.

Wei C., Dai S., Xu H., Wang H. (2020). Cultural worldview and cultural experience in natural tourism sites. Journal of Hospitality and Tourism Management, 43: 241-249.

Ustawa z dnia 16 kwietnia 2004 o ochronie przyrody.

Badania zostały sfinansowane w ramach projektu GEO-INTER-APLIKACJE - wysokiej jakości interdyscyplinarny program studiów doktoranckich POWR.03.02.00-00-I027/17.

\section{The importance of cultural heritage for tourism development in the National Park of the Stable Mountains}

The growing tourist traffic in the Stołowe Mountains generates the need for its deglomeration, which is possible, among others, by through the use of cultural heritage objects. The aim of the article is to determine its significance for the development of tourism in the studied area. The text presents the cultural attractions visited as well as the genera overviev of cultural attractions and resources in the PNGS area. The methodology of the conducted research included obtaining data from tourists using an interview questionnaire and field inventory. The cultural heritage of the Stolowe Mts. is a complementary motivation for tourist trips. Cultural tourism develops mainly in towns, and cultural resources, located in the park area, require promotion and sharing, e.g. in the form of thematic routes.

Translated by Artur Żyto 